\title{
Effects of Brush Control and Game-bird Management on Nongame Birds
}

\author{
BRADLEY J. GRUVER AND FRED S. GUTHERY
}

\begin{abstract}
We observed the responses of nongame birds to brush suppression and habitat management for game birds in the Rolling Plains of Texas during 1981-1983. Data from line transects were used to describe density, species diversity, species richness, and equitability. We observed no difference in these variables between untreated sites and sites late sprayed with herbicides in 1969. The density of northern mockingbirds (Mimus polyglottos) was lower on treated than untreated areas, but no other species were affected. Habitat management to favor mourning doves (Zenaida macroura) and bobwhites (Colinus virginianus) was associated with a $54 \%$ increase in combined density of nongame birds and a reduction in equitability. Species diversity and species richness were similar on managed and unmanaged sites. On our study area, past herbicide treatment of mesquite (Prosopis glandulosa) and habitat management for game birds were compatible with nongame birds.
\end{abstract}

Knowledge of the response of nongame bird populations to land use is important because of current emphasis on multiple-use decisions (Buttery and Shields 1975, Crawford 1976). On rangeland nongame birds also are ecologically important because of their role in energy flow, nutrient turnover, and pest control (Weins and Dyer 1975).

In the Rolling Plains of Texas, mesquite suppression is widely practiced to increase forage production for livestock (Dahl et al. 1978). Further, habitats are commonly managed for bobwhites and mourning doves because of their economic and recreational importance. However, effects of these practices on nongame birds

Authors are nongame biologist, Florida Game and Fresh Water Fish Commission, Tallahassee 32301; and associate research scientist, Caesar Kleberg Wildlife Research Institute, Texas A\&I University, Kingsville 78363. At the time of the research, Gruver was a research assistant and Guthery an associate professor, Department of Range and Wildlife Management, Texas Tech University.

Research was funded by the Noxious Brush and Weed Control Program, Texas

Tech University, and the Caesar Kleberg Foundation for Wildlife Conservation.

This is manuscript no. T-9-406, College of Agricultural Sciences, Texas Tech University.

Manuscript accepted 29 August 1986. are poorly understood. Consequently, we described responses of nongame-bird populations to brush suppression and game-bird management in northwest Texas.

\section{Study Area and Methods}

The study was conducted on the 64,600-ha Pitchford Ranch in Dickens and King counties, Texas, from June 1981 to July 1983. The area had a midlatitude semiarid climate with dry winters and summers and low humidity. Mean annual temperature is $16.7^{\circ} \mathrm{C}$ and mean annual precipitation is $52 \mathrm{~cm}$ (Orton 1970).

Two study sites were established in an area that had been treated with herbicides, and 2 in an untreated area. One study site in each brush treatment was managed to favor game birds, resulting in 4 distinct sites: treated-managed (TM, $45.3 \mathrm{ha}$ ), treated-unmanaged (TU, 55.0 ha), untreated-managed (UM, 76.2 ha), and untreatedunmanaged (UU, $60.4 \mathrm{ha}$ ).

The treated area was sprayed with 2,4,5-T (2,4,5-trichlorophenoxy acetic acid) by truck sprayer in May and June 1969. Previously, the area had been aerially sprayed with 2,4,5-T in June 1964 and 2,4,5-T + Silvex in May and June 1954. Dead brush stems were left standing (Fig. 1). Herbicide treatment had no effect on the density of brush stems, but reduced the proportion alive from $88 \%$ to $9 \%$ (Gruver 1984).

Game-bird management included annual discing of strips 6 to 10 $\mathrm{m}$ wide and about $600 \mathrm{~m}$ long such that $8 \%$ of each managed site was disturbed, constructing brush shelters (1/1.8 ha on the TM site, 1/1.5 ha on the UM site), and establishing supplemental feeders at 1/25 ha on both managed areas. A 2:1:1 mixture of $20 \%$ protein laying ration, corn, and sorghum was fed from December 1981 to July 1983.

Four linear transects were established on each study site to estimate the density of nongame birds. Transects were parallel and spaced about $120 \mathrm{~m}$ apart, except in the UM site were 2 lines were $240 \mathrm{~m}$ apart and divided to form 4 transects. Sets of 4 transects 


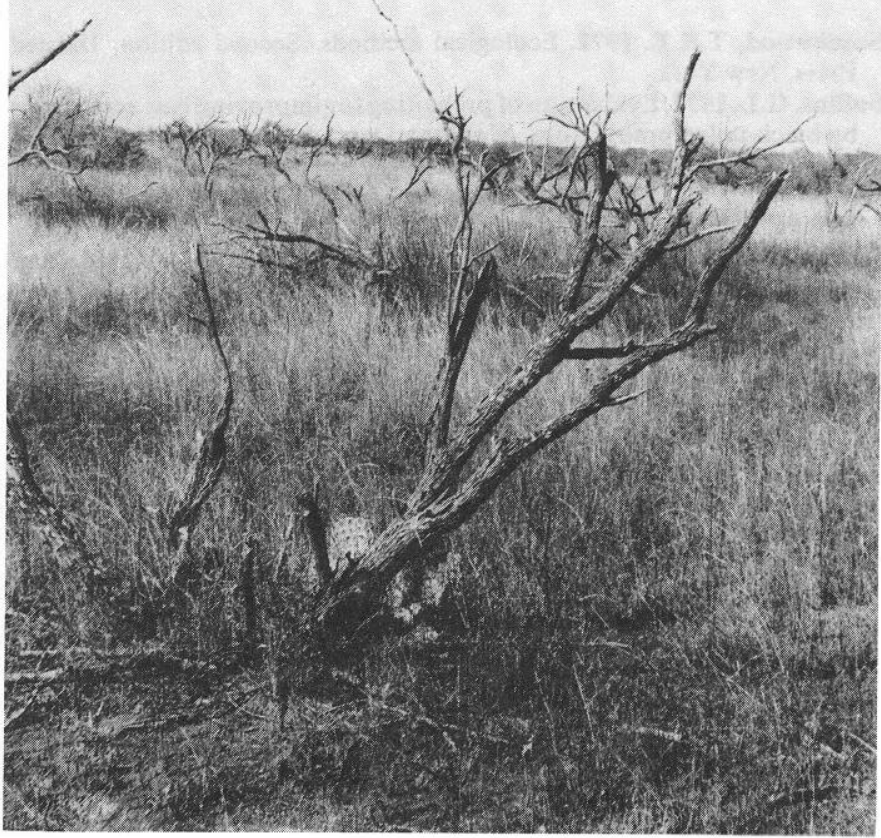

Fig. 1. Mesquite stems were left standing on the treated study area. This site was last sprayed 13 years before the picture was taken.

totaled about $1.8,3.3,3.3$, and $3.5 \mathrm{~km}$ on the TM, TU, UM, and UU sites, respectively. Counting took place during October, January, April, and July of 1981-1982 and 1982-1983. Each transect was walked twice in the morning and twice in the evening during a sampling month, thus creating 4 sampling periods. Sampling was conducted during the first and last 3 hours of daylight.

Birds were identified to species and the $10-\mathrm{m}$ band parallel to the transect in which they occurred was recorded. The computer program TRANSECT (Burnham et al. 1980) was used to calculate effective strip width. Data were pooled across seasons, study sites, and sampling periods in the calculation of strip width. Combined density of nongame birds, density of selected species and groups, species diversity (MacArthur and MacArthur 1961), species richness, and equitability (Tramer 1969) were calculated for each year $X$ season $X$ study site $X$ sampling period combination. Because there was only $1 \mathrm{df}$ for brush-control and management effects, it was pointless to conduct analysis of variance. Therefore, we present descriptive statistics.

\section{Results}

A total of 1,117 nongame birds was observed in 873 flushes during the walking of $1,523.2 \mathrm{~km}$ of transect. Thirty-eight species of nongame birds were observed.

Brush treatment had no effect on nongame-bird diversity, species richness, equitability (Table 1), or combined density (Table 2). However, treatment reduced densities of northern mockingbirds (Table 2). As a group, grassland sparrows appeared more abundant in the treated than untreated area. This group included Cassin's (Aimophila cassinii), clay-colored (Spizella pallida), field (S. pusilla), grasshopper (Ammodramus savannarum), and vesper (Pooecetes gramineus) sparrows.

Game-bird management had no effect on species diversity or species richness of nongame birds but was associated with an $8 \%$ decline in equitability (Table 1) and an increase in combined density (Table 2). Northern mockingbirds, grassland sparrows, and brushland sparrows appeared more abundant on managed than unmanaged sites (Table 2). The group of brushland sparrows included black-throated (Amphispiza bilineata), lark (Chondestes grammacus), and white-crowned (Zonotrichia leucophrys) sparrows. A combined group of other uncommon species which indi-
Table 1. Mean population attributes, pooled over 2 years, 4 seasons, and 4 sampling periods, for nongame birds on sites treated and not treated for brush suppression and managed and not managed for game birds, Dickens County, Tex., 1981-1983.

\begin{tabular}{lcclcc}
\hline \hline & \multicolumn{2}{c}{ Treated } & & \multicolumn{2}{c}{ Untreated } \\
\cline { 2 - 3 } \cline { 6 - 7 } Attribute & Managed & Unmanaged & & Managed & Unmanaged \\
\hline Diversity & 1.00 & 1.0 & & 1.1 & 1.0 \\
Species richness & 3.4 & 3.5 & & 3.6 & 3.6 \\
Equitability & 0.83 & 0.90 & & 0.85 & 0.91 \\
\hline
\end{tabular}

Table 2. Mean densities (N/40 ha) of selected species and groups of nongame birds, pooled over 2 years, 4 seasons, and 4 sampling periods, on sites treated and not treated for brush suppression and managed and not managed for game birds, Dickens County, Tex., 1981-1983.

\begin{tabular}{|c|c|c|c|c|}
\hline \multirow[b]{2}{*}{ Species or group } & \multicolumn{2}{|c|}{ Treated } & \multicolumn{2}{|c|}{ Untreated } \\
\hline & Managed & Unmanaged & Managed & Unmanaged \\
\hline All birds & 78.9 & 49.9 & 57.1 & 43.1 \\
\hline Grassland sparrows & 32.4 & 10.1 & 18.4 & 11.5 \\
\hline $\begin{array}{l}\text { Brushland sparrows } \\
\text { Western meadowlark }\end{array}$ & 14.8 & 5.9 & 5.7 & 3.3 \\
\hline $\begin{array}{l}\text { (Sturnella neglecta) } \\
\text { Northern mockingbird }\end{array}$ & 8.4 & 12.6 & 15.5 & 12.6 \\
\hline $\begin{array}{l}\text { (Mimus polyglottos) } \\
\text { Scissor-tailed flycatcher }\end{array}$ & 6.0 & 1.7 & 5.2 & 3.8 \\
\hline $\begin{array}{l}\text { (Muscivora forficata) } \\
\text { Golden-fronted } \\
\text { woodpecker }\end{array}$ & 4.6 & 4.6 & 3.8 & 5.7 \\
\hline (Melanerpes aurifrons) & 1.5 & 1.5 & 0.7 & 2.2 \\
\hline Other species & 11.0 & 8.6 & 8.0 & 4.0 \\
\hline
\end{tabular}

vidually accounted for less than $4 \%$ of observations was also more abundant on managed areas. Golden-fronted woodpeckers (Melanerpes aurifrons), conversely, were more abundant on unmanaged than managed sites.

\section{Discussion}

Although immediate effects of herbicide treatment to suppress mesquite could not be determined, conditions $12-13$ years posttreatment had little influence on the nongame bird population of our study area. This probably resulted because the avifauna consisted largely of species that foraged and nested in grass or lowbrush habitats. These were also accessible to mobile nongame birds. Further, treated and untreated areas were structurally similar in density of brush stems; total coverage by forbs, grasses, and bare ground; and profile of herbaceous vegetation (Gruver 1984). Although vegetation composition may affect bird populations (Rice et al. 1984), structure is also important (James 1971, Whitmore 1975).

Northern mockingbirds were the only species with reduced numbers on the treated area. These birds may have been more abundant on the untreated than treated area because a greater number of large $(>5 \mathrm{~m})$ trees was available on the untreated area. Larger trees were used as song posts by mockingbirds during late winter through summer.

Combined density of nongame birds averaged $54 \%$ higher in sites managed for game birds than in unmanaged sites. The increase was due to increase in the density of several species rather than 1 or 2 species, including primarily grassland sparrows (defined earlier) and a group of uncommon birds that individually accounted for less than $4 \%$ of all observations. These birds, mostly granivores, may have responded to the increased availability of seed-producing forbs on the disced strips of managed sites (Gruver 1984). Nongame birds, particularly sparrows, also used supple- 
mental feeders.

Equitability appeared higher on unmanaged than managed sites. This occurred mainly because we observed a higher proportion of grassland sparrows on the managed site. This group accounted for $37 \%$ of managed-site observations, but only $24 \%$ of unmanagedsite observations.

Golden-fronted woodpeckers were the only species significantly less abundant in managed than unmanaged areas. Many of these birds were often seen in a small part of the UU site that had a higher density of large mesquite trees than were available in the surrounding area. Transects on other sites did not intersect similar habitat.

Our results suggest that in northwest Texas nongame bird populations are not affected by herbicide treatments of brush after 12 to 13 years have elapsed where dead mesquite stems were left standing (Fig. 1). Our findings support the conclusion of Webb and Guthery (1983) that habitat management to favor game birds in this region appears compatible with nongame birds.

\section{Literature Cited}

Burmham, K.P., D.R. Anderson, and J.L. Laake. 1980. Estimation of density from line transect sampling of biological populations. Wildl. Monogr. 72.

Buttery, R.F., and P.W. Shields. 1975. Range management practices and bird habitat values. P. 183-189. In: D. Smith (ed.) Proc. Symp. Manage. Forest Habitat for Nongame Birds. USDA Forest Serv. Gen. Tech. Rep. WO-1.
Crawford, J.A. 1976. Nongame wildlife: the role of the university. Wildl. Soc. Bull. 4:116-119.

Dahl, B.E., R.E. Sosebee, J.P. Goen, and C.S. Brumley. 1978. Will mesquite control with 2,4,5-T enhance grass production? J. Range Manage. 31:129-131.

Gruver, B.J. 1984. Management and live-brush density effects on avifauna in northwest Texas. Ph.D. Thusis, Texas Tech Univ., Lubbock, Tex.

James, F.C. 1971. Ordinations of habitat relationships among breeding birds. Wilson Bull. 83:215-236.

MacArthur, R.H., and J.W. MacArthur. 1961. On bird species diversity. Ecology 42:594-598.

Orton, R.B. 1970. Climate. P. 63-64. In: C.L. Girdner, Jr., and W.E. Richardson. Soil survey of Dickens County, Texas. USDA Soil Conserv. Serv.

Rice, J., B.W. Anderson, and R.D. Ohmart. 1984. Comparison of the importance of different habitat attributes to avian community organization. J. Wildl. Manage. 48:895-911.

Tramer, E.J. 1969. Bird species diversity: components of Shannon's formula. Ecology 50:927-929.

Webb, W.M., and F.S. Guthery. 1983. Avian response to habitat management for northern bobwhites in northwest Texas. J. Wildl. Manage. 47:220-222.

Weins, J.A., and M.I. Dyer. 1975. Rangeland avifaunas: their composition, energetics, and role in the ecosystem. P. 146-182. In: D. Smith (ed.) Proc. Symp. Manage. Forest Habitat for Nongame Birds. USDA Forest Serv. Gen. Tech. Rep. WO-1.

Whitmore, R.C. 1975. Habitat ordination of passerine birds of the Virgin River Valley, southwestern Utah. Wilson Bull. 87:65-74.

\section{Annual Meeting Abstracts}

The Florida Section is selling and distributing the Proceedings and Abstracts from the 1986 39th Annual Meeting. The following is a list of prices for these:

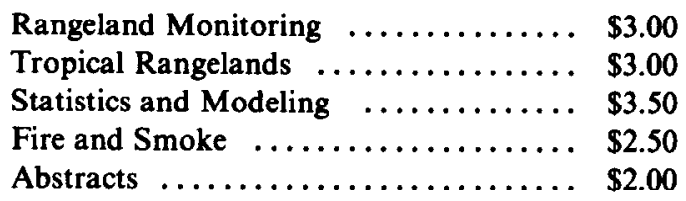

For ordering these, please send to: Cliff Lewis, School of Forest Resources, University of Florida, Gainesville, FL 32611, (904)3924826.

People who want to get copies they did not pick up in Florida, should speak directly to Cliff.
In addition, the 1985 and 1986 International Rangelands Development Symposium Proceedings can be purchased at $\$ 15.00$ each from the following people:

1985 International Rangeland Resource Development Symposium:

Office of Conferences and Institutes

202 Van Doren Hall

Washingston State University

Pullman, WA 99164-5220

1986 International Rangeland Development Symposium: R. Dennis Child c/o Winrock International Route 3, Petit Jean Mt. Morrilton, AR 72110 